2020. № 10. URL: http://www.dy.nayka.com.ua/?op=1\&z=1798 (access date: 20.02.2021). DOI: 10.32702 / 2307-2156-2020.10.35

5. Maistrenko A. A. Normative and legal support of electronic document management in Ukraine: information-analytical review // Archives of Ukraine. 2016. № 3-4. Pp. 58-82.

6. Melnychuk L. I., Golovchenko M. M. Questions of introduction of electronic document circulation in public authorities. 2019. Volume 30 (69). № 1 Part 2. URL: http://efm.vsau.org/ (access date: 02.03.2021).

7. Regulatory framework. Modern trends in electronic document management. URL: https://sites.google.com/site/elektrdokumentoobig/normativno-pravova-baza (access date: 20.02.2021).

8. On accounting and financial reporting in Ukraine: Law of Ukraine of 14.11.2020, № 776-IX. URL: https://zakon.rada.gov.ua/laws/show/ 996-14\#Tex (access date: 02.03.2021).

9. On electronic trust services: Law of Ukraine dated 05.10.2017 № 2155-VIII. URL: https://zakon.rada.gov.ua/laws/show/2155-19\#Text (access date: 02.03.2021).

10. Legal force of EDI and legislation of Ukraine. URL: https://edin.ua/yuridichna-sila-edo-ta-zakonodavstvo-ukra\%D1\%97ni/ (access date: 02.03.2021).

DOI https://doi.org/10.30525/978-9934-26-045-2-17

\title{
СУЧАСНІ МЕХАНІЗМИ ПЛАНУВАННЯ ІНТЕГРОВАНОГО РОЗВИТКУ ГРОМАД В УКРАЇНІ
}

\author{
Вяхірев М. О. \\ аспірант кафедри регіонального управління, \\ місиевого самоврядування та управління містом \\ Начіональної академії державного управління \\ при Президентові Украӥни \\ м. Київ, Україна, \\ заступник Обухівського міського голови \\ Обухівської міської ради \\ м. Обухів, Київська область, Украӥна
}

На сучасному етапі державотворення демократизація публічного управління та адміністрування, передача органам місцевого самоврядування значних повноважень для вирішення питань 
суспільного розвитку громад ставить перед органами управління в Україні складні і неординарні завдання. В умовах об'єднання територіальних громад ці питання набувають значної актуальності. При вдосконаленні процесів реформування української економіки i розвитку ринку місцевих послуг сфера управління в межах територіальної громади стає сферою особливих відносин економіки і влади, i тут мають діяти особливі механізми узгодження соціальних, економічних і політичних інтересів влади, бізнесу та населення. 3 метою досконалої розробки, прийняття і реалізації ефективних рішень суспільні відносини територіальної громади повинні розумітися як єдине ціле, у взаємозв'язку і взаємодії іiі основних елементів. Сьогодні, коли органи місцевого самоврядування наділені значними повноваженнями i можливостями визначати напрямки ефективного соціально-економічного розвитку своїх громад, виникає надзвичайно велика потреба у запровадженні сучасних механізмів у практику діяльності місцевої влади. До таких механізмів, безумовно, відноситься планування інтегрованого розвитку територіальної громади, ефективність застосування якого визнана міжнародною спільнотою.

Актуальність сучасних напрямів планування інтегрованого розвитку громад в Україні полягає в підвищенні важелів багатофункціонального розвитку в економічному зростанні як держави, так $\mathrm{i}$ iii окремих частин, децентралізації влади та передачі значних повноважень на місцевий рівень. Потреба у запровадженні сучасних управлінських практик знає більш вагомою в сучасних реаліях сьогодення.

Сучасний розвиток проєктних підходів в сфері інтегрованого планування територіальної громади як складової частини публічного управління та адміністрування недостатньо досліджений, але у цьому науковому напрямі $\epsilon$ певні наробки. Окремі роботи стосуються європейської інтеграційних процесів, також розглядається інтегрований розвиток міст. Міжнародний досвід інтегрованого розвитку міст достатньо представлений в науковій літературі, але цей досвід потребує вітчизняної адаптації. Сьогодення потребує грунтовного вивчення питань ефективного вирішення проблем інтегрованого розвитку територіальних громад.

Визначення планування інтегрованого розвитку громад передбачається через стимулювання розроблення із залученням громадськості та зацікавлених сторін та затвердження органами місцевого самоврядування концепцій інтегрованого розвитку громад та планів дій з реалізації їх положень. Політика у сфері розвитку громад та територій 
щодо інтегрованого розвитку об'єднаних територіальних громад грунтується на положеннях міжнародного рівня та спрямована на реалізацію Цілі № 11 «Сталий розвиток міст та громад. Забезпечення відкритості, безпеки, життєстійкості й екологічної стійкості міст і населених пунктів» Цілей Сталого Розвитку ООН, затверджених 25 вересня 2015 року Резолюцією Генеральної Асамблеї ООН «Перетворення нашого світу: Порядок денний в області сталого розвитку на період до 2030 року»[1], пункту 11 статті 1 Указу Президента України від 30.09.2019 № 722/2019 «Про Цілі сталого розвитку України на період до 2030 року»[2] та основних положень Лейпцизької хартії «Міста Європи на шляху сталого розвитку» [3]. Основні стратегічні цілі інтегрованого розвитку європейських країн, визначені Лейпцизькою хартією «Міста Європи на шляху до сталого розвитку», беззаперечно, створюють підвалини для напрацювання концепцій інтегрованого розвитку міст не лише у країнах Свропи, а й у тих країнах, що обрали для себе європейський вектор розвитку й продовжують рухатися цим шляхом. Лейпцизька хартія стійких європейських міст грунтується на тому, що механізм інтегрованого підходу до міського планування - це необхідна передумова для довгострокового розвитку європейських міст. Згідно з цим документом, політика інтегрованого розвитку міських територій є процесом, у якому координуються просторові i тимчасові аспекти основних напрямів міського розвитку. Політика інтегрованого розвитку населених пунктів реалізується через так звані інтегровані плани місцевого планування та розвитку. Вони забезпечують просторову, тимчасову і фактичну координацію та інтеграцію різних політик, планові ресурси для досягнення поставлених цілей із використанням специфічних інструментів. Проте, європейські аналітики чітко розуміють, що варто підтримувати та впроваджувати інтегрований розвиток $\mathrm{i}$ для решти самоврядних територій. В умовах об'єднання територіальних громад та подальшого їх розвитку питання синергетичного ефекту поєднання просторового розвитку та пріоритетних завдань місцевого спрямування $\epsilon$ вельми актуальним та визначальним для удосконалення трансформаційних процесів децентралізації повноважень.

Механізми запровадження інтегрованого розвитку територіальних громад в Україні стають більш ефективними через розроблення iз залученням громадськості, учасників та зацікавлених сторін та затвердження органами місцевого самоврядування концепцій інтегрованого розвитку громад та планів дій 3 реалізації їх положень. Концепція інтегрованого розвитку громади - це документ 
стратегічного планування, що визначає довгострокові, міждисциплінарні, просторові та соціально-економічні пріоритети розвитку громади, розробляється із залученням місцевих мешканців та інших заінтересованих сторін, $є$ передумовою розроблення містобудівної документації на місцевому рівні на принципах сталого розвитку 3 метою підвищення якості життя, доступності та рівності можливостей, сприяння розвитку соціальних відносин громадян та ділової активності, оптимізації адміністративної діяльності, координується з державними і регіональними програмами розвитку. Плани дій з реалізації положень концепцій інтегрованого розвитку громад розробляються на основі кращих практик інтегрованого розвитку громад та забезпечують узгодження містобудівної документації, програм соціально-економічного розвитку відповідних адміністративно-територіальних одиниць, цільових програм 3 інших питань місцевого самоврядування, місцевих бюджетів з положеннями концепцій. При цьому потребує подальшої розробки та удосконалення механізми планування інтегрованого розвитку громад в умовах децентралізації.

За підтримки Програми «U-LEAD 3 Свропою» представники органів місцевого самоврядування приймали участь у програмі «Інтегроване просторове планування для об'єднаних територіальних громад». Програма була спрямована на підвищення компетенцій представників громад у питаннях стратегічного просторового розвитку та сталого землекористування. Участь у програмі визначала розробку учасниками концепції стратегічного просторового розвитку під керівництвом міжнародної команди експертів. Цей документ дозволяє запланувати довгостроковий інтегрований розвиток всієї території громад, з урахуванням національного та регіонального контекстів, 3 акцентом на стале використання природніх ресурсів та земель. Відповідаючи на просторові, економічні, екологічні та соціальні виклики, що стоять зараз перед об'єднаною громадою, концепція просторового розвитку передбачає також створення концепцій розвитку соціальної та транспортної інфраструктури, екологічного аудиту та ландшафтного плану території громад, а також розробку пілотних проектів залучення інвестицій [4].

Найбільш за все територіальні громади потребують сьогодні зміцнення економічної складової розвитку та ефективної політики щодо зайнятості населення. При цьому комфортність територій для мешканців має не менше значення, ніж рівень доходів, і ці напрями забезпечуються можливостями впровадження ефективних управлінських практик. Застосування досвіду планування інтегрованого 
розвитку територіальних громад має грунтуватись на науковому дослідженні реального стану всіх сфер життєдіяльності спільноти, визначенні проблем та шляхів їх вирішення, окресленні пріоритетів та поєднанні всіх складових місцевого розвитку.

Процес планування інтегрованого розвитку територіальних громад визначає комплексний підхід до визначення майбутнього розвитку територій з урахування пріоритетів саме цієї спільноти та впорядковує усі містобудівні процеси. Концепція інтегрованого розвитку територій як інструмент підвищення ефективності місцевого врядування повинна бути побудована на чітких принципах, конкретних цілях та визначати спільні просторові наміри громади. Виникнення цілої низки концепцій інтегрованого розвитку місцевих громад визначене особливостями трансформаційного періоду розвитку міст та необхідністю вирішення конкретних проблем.

\section{Література:}

1. «Перетворення нашого світу: Порядок денний в області сталого розвитку на період до 2030 року» Резолюція Генеральної Асамблеї OOH. URL: http://sdg.org.ua/ua/resources-2/344-2030-2015(дата звернення: 19.02.2021).

2. «Про Цілі сталого розвитку України на період до 2030 року» Указ Президента України від 30.09.2019 № 722/2019. URL: https://www.president.gov.ua/documents/7222019-29825 (дата звернення: 01.12.2020).

3. Лейпцизька Хартія «Міста Європи на шляху сталого розвитку». URL: http://2.auc.org.ua/sites/default/files/leypcizka_hartiya.pdf (дата звернення: 10.01.2021).

4. Програма «Інтегроване просторове планування для об'єднаних територіальних громад» URL: https://regionet.org.ua/ua/Rozpochunaetsya_programa_Integrovane_prostorove_planyvannya_dlya_obednanuh_ter utorialnuh_gromad_dedlayn_280918_2634374.html\#page__ (дата звернення: 28.02.2021). 